\title{
Epiphyte survival on skin-shedding macrophytes
}

\author{
G. Russell and C. J. Veltkamp \\ Hartley Botanical Laboratories, The University, Liverpool L69 3BX, England
}

\begin{abstract}
A.BSTRACT: Skin-shedding in Himanthalia elongata (L.) S. F. Gray is more active on receptacles than on vegetative thalli. Elachista scutulata (Sm.) Aresch. and Herponema velutinum (Grev) J. Ag. are epiphytes specific to Himanthalia receptacles. Scanning electron microscope (SEM) studies indicate that their ability to by-pass the antifouling effects of skin-shedding may be due to successful exploitation of cryptostomata and other natural breaks in the host thallus surface. SEM investigation of spore settlement by E. fucicola (Vell.) Aresch. on Fucus vesiculosus L. also revealed dense spore aggregation in the vicinity of cryptostomata.
\end{abstract}

\section{INTRODUCTION}

Periodic abscission of epidermis by Ascophyllum nodosum (L.) Le Jol. has been reported by FilionMyklebust and Norton (1981). Moss $(1982,1984)$ has since demonstrated the shedding of flakes of outer cell wall material from epidermis of Halidrys and other fucoid genera, this process being accomplished without loss of, or damage to, the epidermal cells. Although the 2 accounts differ in detail, they agree that skinshedding is a defence mechanism against fouling by algal epiphytes. The following observations suggest that a slightly modified interpretation of this process may be necessary, as reported briefly by Russell and Veltkamp (1982).

\section{MATERIALS AND METHODS}

Skin-shedding was studied in Himanthalia elongata (L.) S. F. Gray collected from Scarlett Point, Isle of Man, U.K. $\left(53^{\circ} 3^{\prime} 25^{\prime \prime} \mathrm{N}, 4^{\circ} 39^{\prime} 30^{\prime \prime} \mathrm{W}\right)$ in late summer 1981. Portions of thallus were fixed in $5 \%$ formalin-seawater for $24 \mathrm{~h}$, washed in distilled water, then dehydrated in an acetone series of $2.5,5,7.5,10,15,20,25,30,40,50$, $60,70,80,90,100,100 \%$. Two changes were made daily so that dehydration was accomplished in $8 \mathrm{~d}$, slow dehydration having been found to minimise cellwall distortion. Thallus pieces were critical-point dried, coated with $60 \%$ gold-palladium and scanned using a Philips 501B Scanning Electron Microscope (SEM). Development of the epiphytes Elachista scutulata (Sm.) Aresch. and Herponema velutinum
(Grev). J. Ag. on Himanthalia, was also studied by SEM, using the same approach. Spore settlement by $E$. fucicola (Vell.) Aresch. was examined by pipetting a zoospore suspension obtained from fertile thalli into culture vessels containing clean thallus apices of Fucus vesiculosus $\mathrm{L}$. The material was incubated for $24 \mathrm{~h}$ at $10^{\circ} \mathrm{C}$ in an $8-16 \mathrm{~h}$ photoperiod of $11 \mathrm{Wm}^{-2}$. It was then fixed in $5 \%$ formalin-seawater and prepared for SEM as described above. The choice of these species was determined by the fact that they are more readily obtainable and easier to manipulate experimentally than E. scutulata and its host.

\section{RESULTS}

Skin-shedding was most active and most extensive on reproductive tissue, Fig. 1 . The skin always consisted of wall material only, Fig. 2, and, in agreement with Moss (1982), no cells were shed or damaged. The dorsal surface of the vegetative thallus sheds skin less frequently and more in the form of small flakes, while the ventral surfaces were the least active of all. On the ventral surface microbial fouling was evident and there appeared to be little skin-shedding. Transverse sections through developing Elachista scutulata thalli usually revealed the emergence of this epiphyte from conceptacles of Himanthalia, Fig. 3. Located between the expanding epiphyte and its host were 15 to 20 skin layers which the epiphyte had effectively imprisoned (Fig. 4). These layers had been trapped prior to fixation and treatment for SEM, thus dispelling any suspicion that skin-shedding might be an artifact. The rapid 

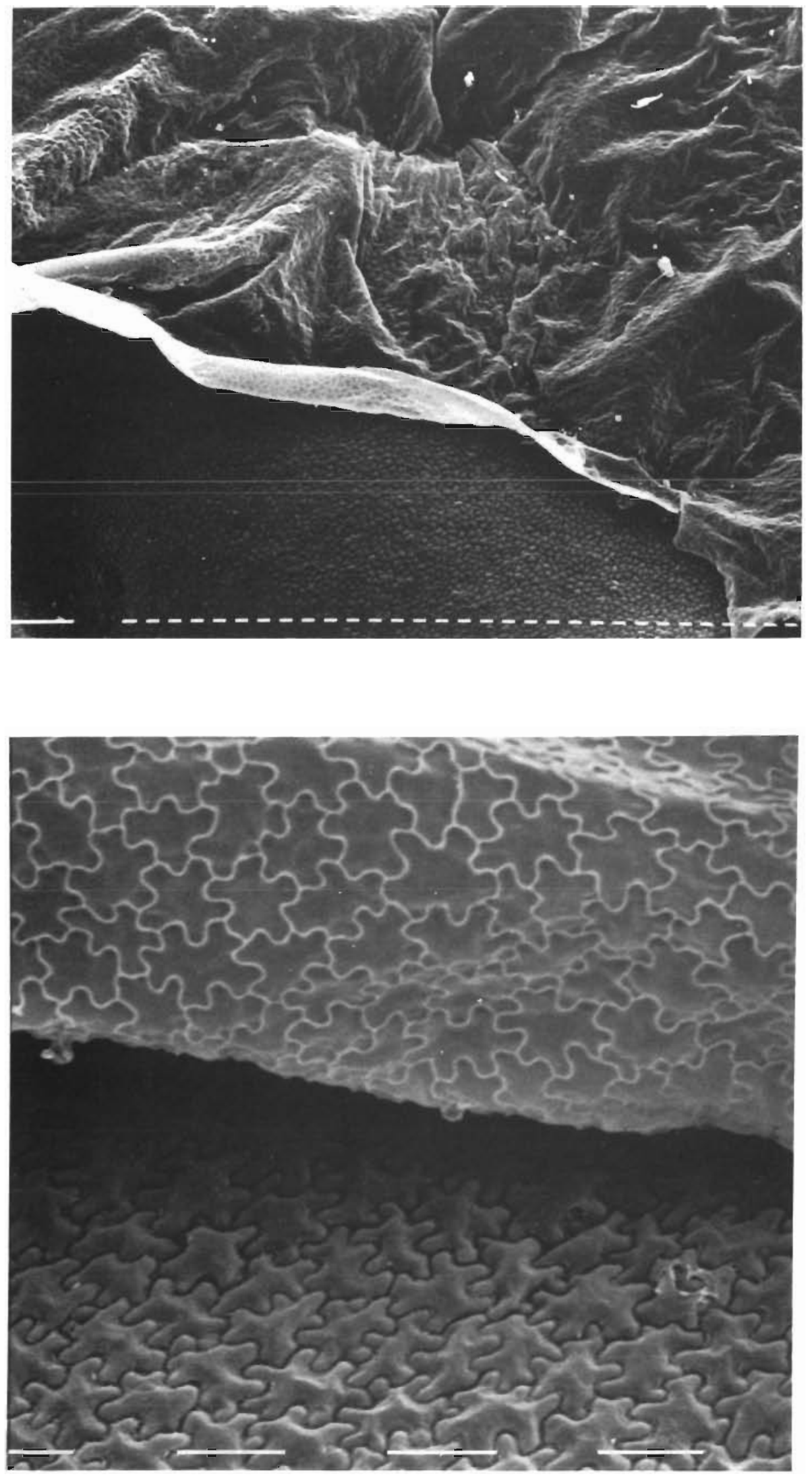

Fig. 1. Himanthalia elongata. Portion of receptacle showing abscission of extensive skin layer. Scale bars $=10 \mu \mathrm{m}$
Fig. 2. Himanthalia elongata. Detail of skin abscission from receptacle. Skin consists of outer wall layers of epidernis plus a small portion of inner wall material. Scale bars $=$ $10 \mu \mathrm{m}$ 
Fig. 3. Himanthalia elongata. Transverse section of receptacle showing emergence of Elachista scutulata from a host conceptacle. Scale bars = $100 \mu \mathrm{m}$
Fig. 4. Tangential section of Elachista scutulata filaments (top), and radial section of Himanthalia elongata (bottom), with accumulation of skin layers trapped between Scale bars $=10 \mu \mathrm{m}$
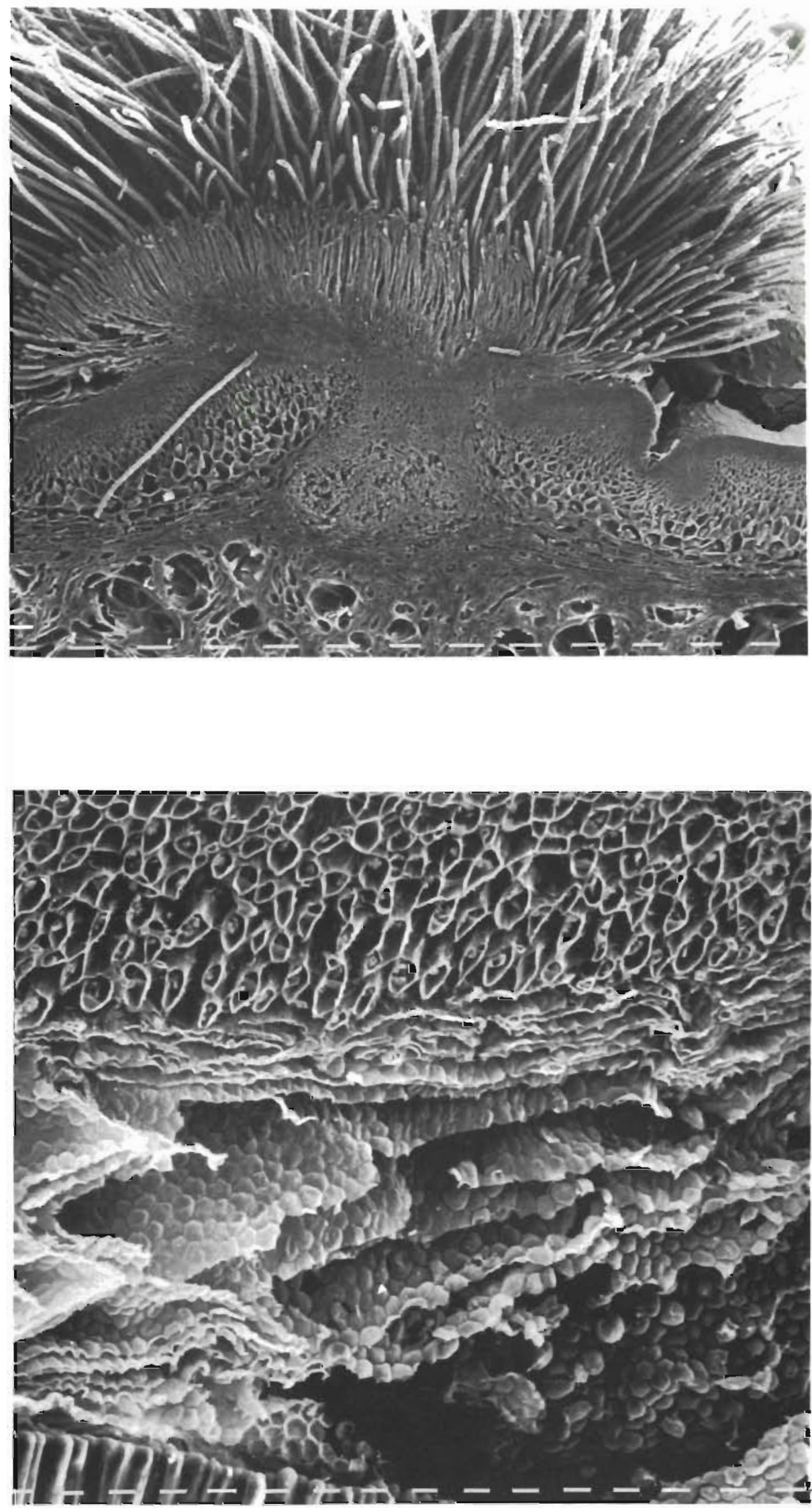


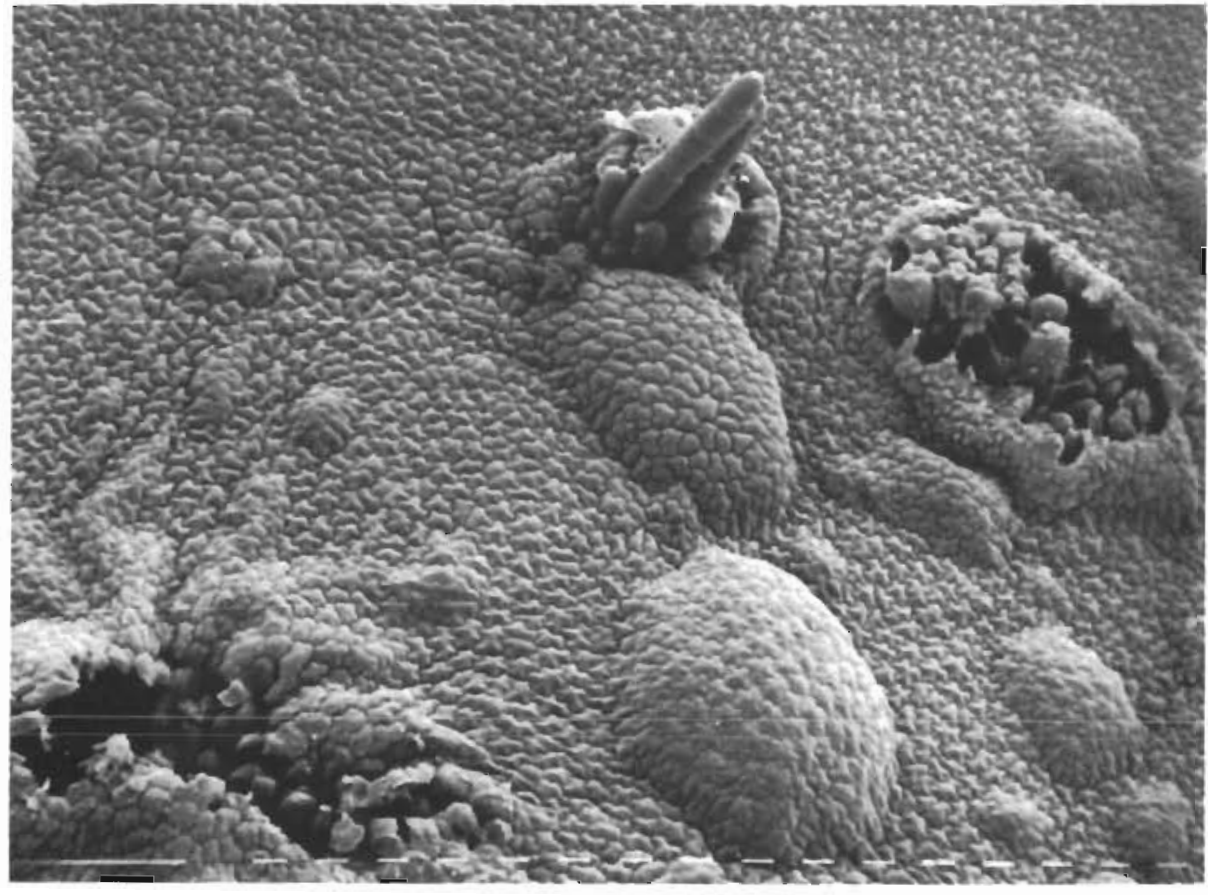

Fig. 5. Herponema velutinum filaments emerging from surface of Himanthalia receptacle which is shedding its skin Scale bars $=10 \mu \mathrm{m}$ expansion of emergent Elachista thalli in nature suggests an abscission frequency which may be measured in days rather than weeks. Herponema filaments were observed to emerge from many parts of the host receptacle and less frequently from conceptacle mouths than E. scutulata; they also grew from host tissue which was actively shedding skin (Fig. 5). However, skin-shedding seemed to slow down with the rapid maturation of this epiphyte, and without the trapping of cell wall layers as in the case of E. scutulata.

Spore settlement by Elachista fucicola proved to be extremely uneven, being very sparse on the open sur-

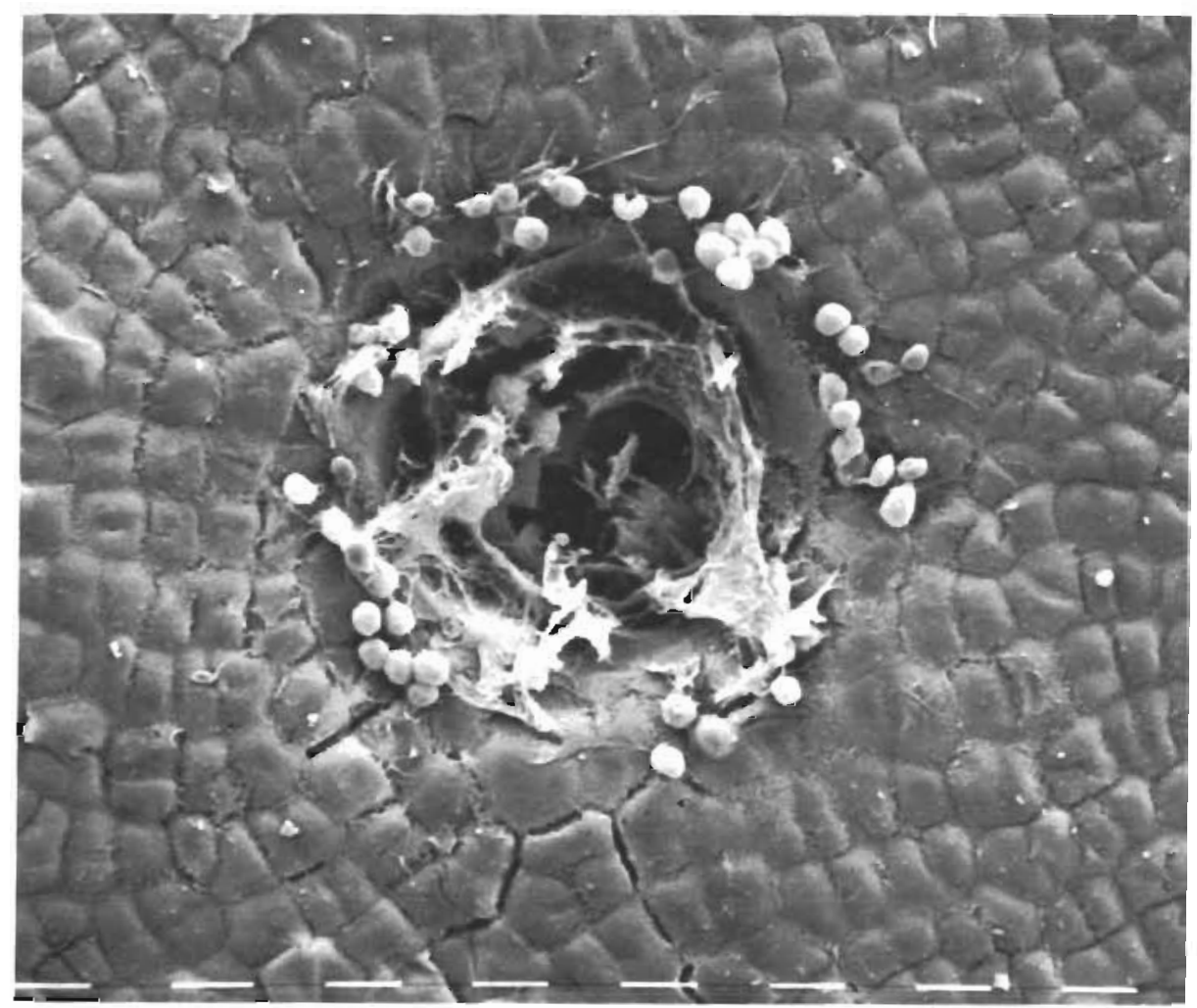

Fig. 6. Fucus vesiculosus. Mouth of developing conceptacle on thallus showing dense aggregate of 40 to 50 settled zoospores of Elachista fucicola. Scale bars $=10 \mu \mathrm{m}$ 
face of the Fucus thallus, but dense in the concavities which marked the positions of developing cryptostomata (Fig. 6).

\section{DISCUSSION}

Elachista scutulata and Herponema velutinum are epiphytes strongly specific to Himanthalia. Their specificity is even more narrow, being restricted to the reproductive parts of the host (Hamel, 1931-39; Levring, 1937). The reproductive thallus at full size is a much larger structure than the vegetative 'button' and its greater surface area would therefore make it more likely to intercept randomly-moving zoospores. On the other hand, the greater longevity of the button might be expected to redress that imbalance a little, and accasional incidences of these epiphytes on vegetative thalli should occur. No such cases have been found either in the course of this investigation or in the literature, however. The absence of these epiphytes from Himanthalia buttons cannot be explained in terms of greater skin-shedding activity on vegetative thalli, since vegetative thalli are less active. It may be deduced, therefore, that the epiphytes possess means of by-passing the antifouling functions of the host receptacle. Preferential spore settlement by E. fucicola in the mouths of cryptostomata, where skin-shedding does not occur, offers a possible explanation. This settlement pattern need not involve cryptostomatal recognition, as spore aggregates were also observed in scratches formed naturally on the Fucus thallus surface. The vegetative thallus of Himanthalia lacks cryptostomata, as do those of Ascophyllum and Halidrys. The occurrence of a sparse epiflora on Ascophyllum (Filion-Myklebust and Norton, 1981) and the noted presence of epiphytes on spent receptacles of the latter (Moss, 1982) are therefore consistent with the view that epiphytes may effect entry into host tissue via apertures in the thallus surface. The frequent associations of E. scutulata with Himanthalia conceptacles also led Hamel (1931-39) to this conclusion.

Skin shedding may serve as a defence mechanism against epiphytes in general, but it may also operate selectively in favour of those epiphytic species that have evolved the means to evade its effects. Skin shedding would appear to be most active in young, rapidly-growing tissue and hence it may also promote gradients in epiphyte distribution as occurs, for example, in Laminaria species (Russell, 1983a, b). It is thus possible for particular host-epiphyte associations to arise in nature through interactive effects such as these.

Acknowledgement. We gratefully acknowledge the careful and vегу constructive criticism of an anonymous referee.

\section{LITERATURE CITED}

Filion-Myklebust, C. C., Norton, T. A. (1981). Epidermis shedding in the brown seaweed Ascophyllum nodosum (L.) Le Jolis. Mar. Biol. Letters 2: 45-51

Hamel, G. (1931-39). Phéophycées de France. Paris

Levring, T. (1937). Zur Kenntnis der Algenflora der norwegischen Westküste. Lunds. Univ. Arsskr 33 (8): 1-147

Moss, B. L. (1982). The control of epiphytes by Halidrys siliquosa (L.) Lyngb. (Phaeophyta, Cystoseiraceae). Phycologia 21: 185-188

Moss, B. L. (1984). 'Skins' and possible relationships in the Fucales. Br. phycol. J.: 19 (in press)

Russell, G. (1983a). Formation of an ectocarpoid epiflora on blades of Laminaria digitata. Mar. Ecol. Prog. Ser. 11: 181-187

Russell, G. (1983b). Parallel growth patterns in algal epiphytes and Laminaria blades. Mar. Ecol. Prog. Ser. 13: 303-304

Russell, G., Veltkamp, C. J. (1982). Epiphytes and antifouling characteristics of Himanthalia (Brown Algae). Br. phycol. J. $17: 239$ 